\title{
A single-session assessment: an opportunity for psychoeducation as intervention
}

\author{
Sharon Ridley ${ }^{1 *}$, Susan Byrne ${ }^{2}$, Anthea Fursland ${ }^{1}$, David Erceg-Hurn ${ }^{1,2}$, Peter McEvoy ${ }^{1,3}$ \\ From 2015 ANZAED Conference: Riding the Waves to Recovery \\ Surfers Paradise, Australia. 21-22 August 2015
}

With limited resources, public clinics tend to have long waiting lists. At the Centre for Clinical Interventions Eating Disorder Programme a 6-month waiting list has been the norm. In May 2014, with 70 patients and a 9 month wait for treatment, we introduced a new assessment process intended to improve efficiency. Within two weeks of being referred, patients are offered a "Singlesession Assessment Appointment" (A0) with a senior clinical psychologist to determine their suitability for the programme. Patients complete questionnaires (demographic and psychometric information), receive a clinical interview, and have their height and weight measured. They receive verbally and in writing: a) psycho-education; b) an orientation to Enhanced Cognitive Behaviour Therapy; and c) alternative services and emergency contacts. Patients provide consent to remain on the waiting list for treatment, and receive a further assessment (A1) immediately prior to commencing treatment. Preliminary findings of $\mathrm{A} 0$ to $\mathrm{A} 1$ changes indicate a reduction of almost $50 \%$ on both waitlist and waiting time, and $>50 \%$ of patients making positive changes (e.g., reduction or cessation of purging). Early results from this new assessment process suggest the potential impact of psychoeducation as early intervention, allowing changes to begin at A0, months before the start of treatment.

\section{Authors' details}

${ }^{1}$ Centre for Clinical Interventions, Australia. ${ }^{2}$ University of Western Australia, Australia. ${ }^{3}$ Curtin University of Technology, Australia.
Published: 23 November 2015

doi:10.1186/2050-2974-3-S1-014

Cite this article as: Ridley et al:: A single-session assessment: an opportunity for psychoeducation as intervention. Journal of Eating Disorders 2015 3(Suppl 1):014.

*Correspondence: sharon_ridley@hotmail.com

${ }^{1}$ Centre for Clinical Interventions, Australia

Full list of author information is available at the end of the article

Submit your next manuscript to BioMed Central and take full advantage of:

- Convenient online submission

- Thorough peer review

- No space constraints or color figure charges

- Immediate publication on acceptance

- Inclusion in PubMed, CAS, Scopus and Google Scholar

- Research which is freely available for redistribution
() Biomed Central 